\title{
LAMBDA-CYHALOTHRIN: AN INSECTICIDE FOR HEMIPTERAN PEST CONTROL IN WHITE CLOVER SEED CROPS
}

\author{
N.C. SCHROEDER, D.B. BAIRD, E.A. UPRITCHARD ${ }^{1}$ \\ and A. SIMEONIDIS ${ }^{2}$ \\ AgResearch, P.O.Box 60, Lincoln \\ ${ }^{1}$ Crop Care Holdings Ltd., P.O.Box 16-150, Hornby, Christchurch \\ ${ }^{2}$ P.O.Box 98, Taupo
}

\begin{abstract}
Lambda-cyhalothrin was tested in field cages at two rates ( 5 and 10 $\mathrm{g} / \mathrm{ha}$ ) and in white clover (Trifolium repens) field plots at $10 \mathrm{~g} / \mathrm{ha}$. Both rates significantly reduced nymph and adult potato mirid (Calocoris norvegicus) and aphid (Acyrthosiphon spp.) numbers up to 12 and 20 days after treatment (DAT), respectively in the cages. Numbers of aphids and potato mirid nymphs were significantly lower in the $10 \mathrm{~g} / \mathrm{h}$ a treated cages up to 12 DAT. Aphid numbers were significantly reduced in the lambdacyhalothrin treated field plots up to 7 DAT, but there was no difference in potato mirid adult numbers between the treated and control plots. Of the common aphid predators collected, ladybird (Coccinella undecimpunctata) numbers were adversely affected by lambda-cyhalothrin application up to 14DAT, while Tasmanian lacewing (Micromus tasmaniae) and harvestmen (Phalangium opilio) numbers were not reduced.
\end{abstract}

Keywords: Lambda-cyhalothrin, potato mirid, aphids, white clover

\section{INTRODUCTION}

The clover casebearer moths (Coleophora spissicornis and C. frischella) used to be regarded as the major white clover seed pests in Canterbury. With the successful introduction and establishment of the parasitoids (Bracon variegator and Chrysonotomyia trifolii), casebearer moths had become less numerous by the late 1970's (Pearson 1989) and been replaced by potato mirids (Calocoris norvegicus Gmelin) and bluegreen lucerne aphid (BGLA) (Acyrthosiphon kondoi Shinji).

Schroeder and Clifford (1996) found potato mirid and BGLA were the two most abundant insect pests collected during the 1994-95 growing season in 24 Canterbury white clover (Trifolium repensL.) seed crops. Both species occurred early in the growing season (mid November to late December) when maximum plant stolon growth and flower development was taking place. The highest incidence of potato mirid nymphs $\left(40 / \mathrm{m}^{2}\right)$ occurred in the crop edge, while BGLA numbers reached a maximum of $800 / \mathrm{m}^{2}$ within fields. Feeding injury by potato mirid salivary enzymes was localised to the feeding site resulting in damaged flowerheads. Potato mirid nymphs at a density of $34-48 / \mathrm{m}^{2}$ have been shown to result in reductions of up to $148 \mathrm{~kg} / \mathrm{ha}$ losses in white clover seed yield, corresponding to a loss of $\$ 592 / \mathrm{ha}$ at $\$ 4 / \mathrm{kg}$ seed (Schroeder 1995). The damage caused by BGLA is not fully understood and requires further investigation. BGLA has been associated with stunting and deformation of lucerne plants and significant yield losses (Summers and Coviello 1984) and Trought (1977) predicted a $20 \%$ seed yield loss could occur in white clover crops with infestations above 16 per flowerhead.

There are four insecticides currently registered for use in New Zealand white clover seed crops. Of these, pirimicarb and fluvalinate are registered for use against aphids but none are registered for use against potato mirid. Wightman and Whitford (1982) demonstrated pirimicarb to reduce aphid numbers but to have no effect on potato mirid numbers. 
Schroeder and Chapman (1995) field tested fluvalinate against aphids in white clover and found that when applied at $36 \mathrm{~g} / \mathrm{ha}$, the inscecticide controlled populations for at least 15 days after treatment. The effect of fluvalinate on potato mirid numbers was not evaluated because field edges, where potato mirids occur, were not included in sampling positions.

The synthetic pyrethroid lambda-cyhalothrin has been found to be effective at low application rates against insect pests of many crops, while having no observed lethal or sublethal effects on foraging honeybees (Gough and Wilkinson 1984). Lambdacyhalothrin is currently recommended for use against caterpillar pests on beans, onions, maize/sweetcorn, tomatoes, forage and vegetable brassicas and thrips on onions in New Zealand (O'Connor 1996). The low toxicity of this insecticide to foraging honeybees and its ability to control a range of hemipteran pests (Gough and Wilkinson 1984) make lambda-cyhalothrin a potential candidate for control of potato mirid and aphids in white clover and other herbage seed legume crops grown in New Zealand. This paper reports on the efficacy of lambda-cyhalothrin against potato mirid and aphids in two white clover field experiments.

\section{Field cage evaluation}

\section{MATERIALS AND METHOD}

This experiment was conducted in a 8 ha irrigated first year (cv Grasslands Huia) white clover seed crop located $5 \mathrm{~km}$ west of Lincoln, Canterbury. Twenty woodenframed field cages (90 x 90 x $90 \mathrm{~cm}$ high) were covered in fine netting and firmly pegged at $2.5 \mathrm{~m}$ intervals in two parallel lines $1.5 \mathrm{~m}$ apart. Pyrethrum (14 g/litre pyrethrum a.i., $56.5 \mathrm{~g} /$ litre piperonyl butoxide) was applied to all cages at $0.7 \mathrm{~g}$ in 9 litres of water on 5 December 1995 to kill resident insects. On December 8, two treated cages and one control cage in each of three replicates were infested with 40 potato mirid nymphs (combination of second, third and fourth instars), 12 potato mirid adults and 200 BGLA. The potato mirids were collected with a sweep net from a stand of lucerne (Medicago sativa L.) (cv Grasslands Otaio) and aphids from a nearby clover field at TaiTapu. The remaining replicate received 200 (parasitoid-free) laboratoryreared pea aphids (Acyrthosiphon pisum Harris) instead of BGLA, because field populations showed evidence of parasitism.

A randomised design consisting of four replicates and three treatments was used. Treatments were lambda-cyhalothrin (Karate, $50 \mathrm{~g} /$ litre EC) at 5 and $10 \mathrm{~g} / \mathrm{ha}$ applied with a knapsack sprayer, in 85 and $170 \mathrm{ml}$ water per cage on December 14, respectively. Untreated caged plots served as controls. The cages were sampled 5, 12 and 20 days after treatment (DAT) with lambda-cyhalothrin. Each replicate had three control cages to enable a different cage to be used at each sampling period. This removed the possibility of uncollected insects influencing subsequent measurements. This was not anticipated to be a significant source of error in the lambda-cyhalothrin treated cages, therefore the cages were reused for each sampling.

Five DAT, the infested cages were sampled with a suction sampler covering a 201 $\mathrm{cm}^{2}$ area to collect all surviving insects, which were identified and counted.

Seven DAT the treated and second control cages were infested with 20 potato mirid nymphs and 12 adults in all the replicates and 200 BGLA collected from the field (replicate 1) or 200 laboratory reared pea aphids (replicates 2-4). Surviving insects were collected by suction sampler 12 DAT. Fourteen DAT, cages were re-infested with 12 and 30 potato mirid nymphs and adults (respectively) and 200 pea aphids (replicates 1 and 2) or 40 potato mirid adults and 200 pea aphids (replicates 3 and 4). Surviving insects were collected 20 DAT.

The insect count data were analysed using a generalized linear model with binomial distributed errors.

\section{Field plot evaluation}

Two $10 \times 4 \mathrm{~m}$ plots, $5 \mathrm{~m}$ apart, were established out on the edge of a first harvest white clover (cv. Grasslands Huia) seed crop at TaiTapu. Lambda-cyhalothrin was applied at $10 \mathrm{~g} / \mathrm{ha}$ in 250 litres water/ha to one of the plots using a precision sprayer on 15 December, 1995. The other plot was untreated (control). Pegs were used to mark 
the centre of each plot at 1,2 and $3 \mathrm{~m}$ from the crop edge into the crop. Each plot was sub-sampled at these positions. An area of $0.804 \mathrm{~m}^{2}$ was suction sampled 1 and $3 \mathrm{~m}$ from the crop edge into each plot the day before lambda-cyhalothrin was applied to give pre-treatment numbers of arthropods present. Three DAT, when there was a significant difference in insect numbers between treatments, a smaller suction sample of $0.201 \mathrm{~m}^{2}$ was taken at positions 1,2 and $3 \mathrm{~m}$ from the crop edge into each plot, followed by a larger sample of $0.402 \mathrm{~m}^{2}$ at 7, 14 and 22 DAT at the same distances. Suction samples were taken, alternately, from the right or left of the pegs over consecutive sampling periods to reduce collection pressure. Samples were placed into a freezer for later identification and counting of pest and beneficial arthropods.

Data were statistically analysed using analysis of variance. As there was no true treatment replication the variation between sub-samples was used to provide an estimate of variation. This is probably an underestimate of the treatment error. Therefore, any significance (Table 2) should be understood as being indicative only.

\section{Field cage evaluation}

\section{RESULTS}

Lambda-cyhalothrin applied at $10 \mathrm{~g} / \mathrm{ha}$ gave higher levels and longer periods of control of potato mirids and aphids than the $5 \mathrm{~g} /$ ha treatment (Table 1 ). Aphid numbers were significantly lower $(\mathrm{P}<0.001,5$ and $12 \mathrm{DAT})$ during the experiment in the $10 \mathrm{~g} / \mathrm{ha}$, than the $5 \mathrm{~g} / \mathrm{ha}$ treated cages up to 20 DAT $(\mathrm{P}<0.01)$. Cages from both insecticide treatments at 20 DAT had significantly $(\mathrm{P}<0.01)$ fewer aphids recovered than the control cages. Both rates of insecticide significantly $(\mathrm{P}<0.001)$ reduced numbers of potato mirid nymphs and adults 12 DAT, but differences were not significant $(\mathrm{P}>0.05) 20$ DAT.

TABLE 1: Percent survival (SEM) of potato mirids and aphids infested into field cages at 5, 12 and 20 days after lambda-cyhalothrin treatment.

\begin{tabular}{lccc}
\hline & & Days After Treatment & \\
& 5 & 12 & 20 \\
\hline Potato Mirid Nymphs & & & \\
Control & $39(4)$ & $41(5)$ & $16(7)$ \\
5 g a.i./ha & $0(0)$ & $22(4)$ & $15(7)$ \\
10 g a.i./ha & $0(0)$ & $6(3)$ & $30(9)$ \\
Untr v Trtd & $* * *$ & $* * *$ & $\mathrm{~ns}$ \\
5 v. 10 & $\mathrm{~ns}$ & $* *$ & $\mathrm{~ns}$ \\
Potato Mirid Adults & & & \\
Control & $89(4)$ & $88(4)$ & $35(4)$ \\
5 g a.i./ha & $6(3)$ & $46(7)$ & $41(4)$ \\
10 g a.i./ha & $0(0)$ & $29(6)$ & $38(4)$ \\
Untr v. Trtd & $* * *$ & $* * *$ & $\mathrm{~ns}$ \\
5 v. 10 & $*$ & $\mathrm{~ns}$ & \\
Aphids & & & $19(1)$ \\
Control & $58(2)$ & $23(1)$ & $12(1)$ \\
5 g a.i./ha & $12(1)$ & $15(1)$ & $8(1)$ \\
10 g a.i./ha & $3(1)$ & $5(1)$ & $* * *$ \\
Untr v. Trtd & $* * *$ & $* * *$ & $* *$ \\
5 v. 10 & $* * *$ & & \\
\hline
\end{tabular}

ns $=$ not significant, $*=\mathrm{P}<0.05, * *=\mathrm{P}<0.01, * * *=\mathrm{P}<0.001$

\section{Field plot evaluation}

Numbers of potato mirid adults were not significantly $(\mathrm{P}<0.05)$ different between the treated and control plots at any of the sampling dates (Table 2). Potato mirid nymph numbers collected during the experiment were very low. Aphid numbers had, however, significantly decreased $(\mathrm{P}<0.001)$ after insecticide treatment when sampled 
3 and 7 DAT (Table 2). Of the aphid predators collected, adult ladybird numbers (mainly Coccinella undecimpunctata $\mathrm{L}$.) were significantly $(\mathrm{P}<0.05)$ lower in the insecticide treated plot at $3\left(1.8 / \mathrm{m}^{2}\right)$ and $7\left(5.1 / \mathrm{m}^{2}\right)$ DAT compared to 28.2 and $15 /$ $\mathrm{m}^{2}$, respectively, in the control plots. Adult Tasmanian lacewing (Micromus tasmaniae Walker) and havestmen (Phalangium opilio L.) numbers were not significantly different between plots at any stage during the experiment. In the control plot, adult lacewing numbers increased from $8 / \mathrm{m}^{2}$ (ODAT) to $41 / \mathrm{m}^{2}$ (22 DAT) and the average number of harvestmen was $22 / \mathrm{m}^{2}$ during the experiment.

TABLE 2: Potato mirid adults and aphid numbers $/ \mathrm{m}^{2}$ before and after treatment in field plots with and without (control) $10 \mathrm{~g}$ a.i./ha lambda-cyhalothrin.

\begin{tabular}{lccccc}
\hline & \multicolumn{5}{c}{ Days After Treatment } \\
& 0 & 3 & 7 & 14 & 22 \\
\hline Potato Mirid Adults & & & & & \\
Control & 8 & 2 & 0 & 4 & 6 \\
Treated & 4 & 0 & 0 & 3 & 3 \\
LSD (5\%) & 7 & 5 & 0 & 6 & 6 \\
Aphids & & & & & \\
Control & 4290 & 3069 & 2778 & 19 & 23 \\
Treated & 3918 & 198 & 192 & 2 & 13 \\
LSD (5\%) & 695 & 685 & 978 & 19 & 20 \\
\hline
\end{tabular}

$\mathrm{LSD}=$ least significant difference between means which is statistically significant at the $5 \%$ level.

\section{DISCUSSION}

Lambda-cyhalothrin was shown to reduce numbers of potato mirid nymphs and adults and also BGLA and pea aphids. Control of all insects tested was higher and more prolonged when lambda-cyhalothrin was applied at $10 \mathrm{~g} / \mathrm{ha}$ rather than $5 \mathrm{~g} / \mathrm{ha}$. Lambda-cyhalothrin had a more pronounced effect on aphids than potato mirids in the field cage experiment and kept aphid numbers reduced for at least eight days longer $(\mathrm{P}<0.01)$. While field populations of aphids were significantly reduced by $10 \mathrm{~g} / \mathrm{ha}$ lambda-cyhalothrin up to $7 \mathrm{DAT}$, the resident potato mirid adult populations were not shown to be affected. In view of successful control of potato mirids in the cage experiment, however, further investigation of lambda-cyhalothrin is warranted and it may be that higher concentrations are required to control potato mirids in the field. Blair (1991) found that high concentrations of lambda-cyhalothrin appeared to have a repellent and/or antifeedant effect on insects. This may have been partly responsible for higher mortality in the cages than in the field trial. Potato mirids may have been able to move away from insecticide treated areas in the field but not within the cages. The inclusion of a wetting agent in lambda-cyhalothrin application may increase its effectiveness and is recommended by O'Connor (1996) at $25 \mathrm{ml} / 100$ litres of spray mix in all uses. A wetting agent was not used in these trials.

The field trial was conducted when aphid numbers had reached high levels. The sudden reduction of numbers between 7 (December 22) and 14 DAT in both plots were similar to those found by Rohitha and Penman (1986) and was attributed to aphid flights out of the trial area. Aphid flights are triggered by their density and the resultant reduction in host food quality (Beck 1968). This would suggest that the treatments were applied too late in the season and may have been more effective in controlling numbers if applied in late November to early December. Potato mirid nymphs appear to be more susceptible to lambda-cyhalothrin than adults. A possible control strategy for potato mirids may, therefore, be to kill nymphs coming into the field at the crop edges thus preventing highly mobile adults from invading the crop (Schroeder and Chapman 1996). 
Of the major beneficial arthropod predators described by Schroeder and Clifford (1996), adult ladybirds were the only species observed to be adversely effected by lambda-cyhalothrin treatment. Rotrekl (1994) found that $6.25 \mathrm{~g} / \mathrm{ha}$ lambda-cyhalothrin was particularly injurious to coccinellids. The impact of ladybirds, lacewings and harvestmen on aphid numbers in the field is not fully understood as most studies have concentrated on laboratory experiments. The aphid predators present in the field trial did not prevent aphid numbers reaching up to $4290 / \mathrm{m}^{2}$ on December 14 (Table 2) and could be the result of predator lag. An earlier application of lambda-cyhalothrin may have prevented aphid numbers reaching a high level and allowed predators to regulate the population at a lower level. Further investigation is necessary to ascertain the economic effectiveness of lambda-cyhalothrin. The results suggest that the application of this insecticide may be refined to enable it to be used effectively against potato mirid and aphids in white clover seed crops.

\section{ACKNOWLEDGEMENTS}

We would like to thank Peter Clifford (AgResearch, Lincoln) for advise on aspects of white clover agronomy, Bruce Chapman (Entomology, Lincoln University) for editorial help, Jim Macartney and John Morrish for the use of their white clover seed crops.

\section{REFERENCES}

Beck, S.D., 1968. Insect Polymorphism. Academic Press. New York and London. $288 \mathrm{pp}$.

Blair, B.W., 1991. The concentration of lambdacyhalothrin and its effects on the cutworm Agrotis segetum (Lepidoptera: Noctuidae). Bull. Entomol. Res., 81: 143-145.

Gough, H.J. and Wilkinson, W., 1984. PP321- effect on honey bees. 1984 British Crop Prot. Conf. Pests and Diseases. Vol 1: 331-335.

O’Connor, B., 1996. 1996 Novachem Manual. Novachem Services Limited, Swiftprint Centre Ltd., Palmerston North, N.Z., 282.

Pearson, W.D., 1989. Coleophora frischella L., whitetipped clover casebearer, $C$. spissicornis Haworth, banded clover casebearer (Lepidoptera: Coleophoridae). Pp. 73-85. In: A Review of Biological Control of Invertebrate Pests and Weeds in New Zealand 1874-1987. P.J.Cameron, R.L.Cameron, R.L.Hill, J.Bain and W.P.Thomas (Eds). DSIR Entom. Div., CAB Int. Inst. Biol. Control.

Rohitha, B.H. and Penman, D.R., 1986. Flight of the bluegreen aphid Acyrthosiphon kondoi Shinji (Homoptera: Aphididae) 1. Flight periodicity and phenological relationships. N.Z. J. Zool., 13: 203-207.

Rotrekl, J., 1994. Effect of insecticides on the beneficial insect fauna in lucerne (Medicago sativa L.). Ochrana-Rostlin, 30: 67-77.

Schroeder, N.C., 1995. Hemipteran pest damage assessment and management in white clover seed crops. M.Agr.Sci Thesis, Lincoln University, New Zealand.

Schroeder, N.C. and Chapman, R.B., 1995. The impact of two insecticides on hemipteran pests and beneficial arthropods in a white clover seed crop.Proc. 48th N.Z. Plant Prot. Conf., 170-174.

Schroeder, N.C. and Clifford, P.T.P., 1996. The incidence of insect pests and their arthropod predators in 24 Canterbury white clover seed crops. Joint Proc. N.Z. Grass. Assoc. and Agron. Soc. N.Z., White Clover Symposium: 29-33.

Summers, C.G. and Coviello, R.L., 1984. Impact of Acyrthosiphon kondoi (Homoptera: Aphididae) on alfalfa: field and greenhouse studies. J. Econ. Entomol. 77: 10521056.

Trought, T.E.T., 1977. Control of blue-green lucerne aphid on white clover seed crops. Proc. 30th N.Z. Weed and Pest Control Conf., 188-191.

Wightman, J.A. and Whitford, D.N.J., 1982. Integrated control of pests of legume seed crops 1 . Insecticides for mirid and aphid control.N.Z. J. Exp. Agric. 10:209215 . 